\section{GENDER VARIATION \\ IN ACOUSTIC \\ CHARACTERISTICS OF SOUTHERN PA-O LEXICAL TONES $^{1}$}

\section{Sujinat Jitwiriyanont ${ }^{2}$}

\section{บทคัดย่อ}

ภาษาปะโอใต้อยู่ในกลุ่มภาษากะเหรี่ยง สาขาย่อย ทิเบต-พม่า ตระกูลจีน-ทิเบต ในประเทศไทย มี ชุมชนผู้พูดภาษาปะโอใต้อยู่บริเวณถนนพระรามที่ 2 บทความวิจัยนี้ มีวัตถุประสงค์เพื่อศึกษาการแปร ตามเพศของลักษณะทางกลสัทศาสตร์ของ วรรณยุกต์ในภาษาปะโอใต้ ค่าความถี่มูลฐาน

1 (การแปรตามเพศของลักษณะทางกลสัทศาสตร์ของวรรณยุกต์ ในภาษาปะโอใต้) This paper is part of my Ph.D. dissertation on citation tones and tonal coarticulation in $\mathrm{Pa}-\mathrm{O}$ continuous speech. I would like to express my gratitude to Prof. Theraphan Luangthonghum and Prof. David Bradley for their supervision and comments. Financial support from the Thailand Research Fund through the Royal Golden Jubilee Ph.D. Program and Chulalongkorn University (Grant No. PHD/0201/2552) to Prof. Theraphan Luangthongkum and Sujinat Jitwiriyanont is acknowledged. My special thanks go to my Southern $\mathrm{Pa}-\mathrm{O}$ friends and linguistic fellows at Center of Research on Language Diversity, La Trobe University.

2 (ศุจิณัฐ จิตวิริยนนท์) Ph.D. Candidate in Linguistics, Department of Linguistics, Faculty of Arts, Chulalongkorn University
(เฮิรตซ์) ซึ่งแปรตามลักษณะทางกายภาพของเส้น เสียงถูกปรับค่าเป็นเซมิโทนเพื่อลดการแปรระหว่าง บุคคล ค่าเซมิโทนและค่าระยะเวลาจริงของ วรรณยุกต์ทั้ง 6 วรรณยุกต์ (4 วรรณยุกต์ในพยางค์ เป็น และ 2 วรรณยุกต์ในพยางค์ตาย) นำมาคำนวณ และสร้างเส้นแนวโน้มจากสมการพหุนามกำลังสอง เพื่อแสดงการขึ้นตกและรูปร่างของวรรณยุกต์

ผลการศึกษาพบว่า เพศมีอิทธิพลต่อการแปรค่าทาง กลสัทศาสตร์ของวรรณยุกต์ในภาษาปะโอใต้ ความ แตกต่างของวรรณยุกต์ระหว่างเพศชายและเพศ หญิงดังกล่าวนี้พบในพยางค์เป็น (วรรณยุกต์ที่ 1-4) แต่ไม่ชัดเจนในพยางค์ตาย (วรรณยุกต์ที่ 5-6) วรรณยุกต์ที่ 12 และ 4 แสดงความต่างระหว่างเพศ ในแง่การขึ้นตกของวรรณยุกต์ โดยวรรณยุกต์ที่ 1 และ 2 มีความต่างที่เป็นแนวโน้ม กล่าวคือ วรรณยุกต์ที่ 1 มีแนวโน้มเป็นระดับเสียงตก-ขึ้นใน เพศชาย และ ระดับเสียงขึ้นในเพศหญิง วรรณยุกต์ ที่ 2 มีแนวโน้มเป็นระดับเสียงคงที่ในเพศชาย และ ระดับเสียงตกในเพศหญิง ส่วนความต่างของ วรรณยุกต์ที่ 4 ระหว่างเพศชายและเพศหญิงมี ลักษณะจำแนกชัดเจน โดยเป็นระดับเสียงตกในเพศ ชาย และระดับเสียงขึ้น-ตก ในเพศหญิง นอกจากนี้ แม้ว่าวรรณยุกต์ที่ 3 ของเพศชายและเพศหญิงจะมี การขึ้นตกเหมือนกัน แต่มีรูปร่างของวรรณยุกต์ที่ แตกต่างกัน โดยวรรณยุกต์ที่ 3 ของเพศชายมีการ เคลื่อนที่ของระดับเสียงเป็นเส้นโค้งทั้งหมด แต่เป็น 


\author{
เส้นตรงทั้งหมดในเพศหญิง การศึกษาทางกล \\ สัทศาสตร์นี้ชี้ให้เห็นชัดเจนว่าเพศเป็นปัจจัยที่ส่งผล \\ ต่อการแปรของวรรณยุกต์ในภาษาปะโอใต้
}

\begin{abstract}
Southern $\mathrm{Pa}-\mathrm{O}$ (S. Pa-O) is a Karenic language of the Tibeto-Burman subgroup of the Sino-Tibetan language family. In Thailand, there is a large S. Pa-O community around Rama II Road. This study aims to investigate the gender variation in acoustic characteristics of $S$. $\mathrm{Pa}-\mathrm{O}$ lexical tones. $\mathrm{FO}$ in Hertz based on the biological difference of larynx vibrating rate was converted into semitones to normalize cross-speaker differences. Then, semitone and real time values of 6 lexical tones (4 non-checked tones and 2 checked tones) were used to generate $2^{\text {nd }}$ degree polynomial trendlines to show FO contours and shapes.
\end{abstract}

The results reveal a gender effect on acoustic characteristics of $\mathrm{S}$. Pa-O tones. Differences in FO characteristics between the male and the female speakers are found in non-checked tones (T1, T2, T3, and T4). The two checked tones (T5 and T6) do not show distinguishable FO characteristics. The FO gender characteristics of T1, T2 and T4 show differences between genders in terms of $\mathrm{FO}$ contours. The case of $T 1$ and $T 2$ is a tendency. Regarding T1, the male speakers produce the tone with a falling-rising contour and the females with a rising contour. The F0 contours of the males' T2 tend to be level while those of the female's T2 tend to be falling. The gender difference of T4 is dichotomous. The males' T4 is falling, and the females' T4 is rising-falling. Despite a similar FO contour, the T3 of the male and female speakers can be differentiated by the FO shapes. The FO shapes of the males' T3 are all curved, while those of the females' T3 are linear. All in all, the gender variation in $\mathrm{S}$. $\mathrm{Pa}-\mathrm{O}$ tones is confirmed in the acoustic study.

\section{Introduction}

Among Sino-Tibetan languages, $\mathrm{Pa}-\mathrm{O}$ is under-studied. $\mathrm{Pa}-\mathrm{O}$ is a Karenic language of the Tibeto-Burman subgroup. The $\mathrm{Pa}-\mathrm{O}$ language has two dialects: Northern $\mathrm{Pa}-\mathrm{O}$ (N. Pa-O) and Southern Pa-O (S. Pa-O). There are a few linguistic studies on $\mathrm{N}$. Pa-O (Jones, 1961; Burling, 1969; Thanamteun, 2000) and only one study on both N. Pa-O and S. Pa-O (Luangthongkum, 2014). Except for Thanamteun's study of N. Pa-O phonology, all studied $\mathrm{Pa}-\mathrm{O}$ as part of Proto-Karen reconstruction. There is no study focusing on S. Pa-O. After my acoustic study of N. Pa-O tones, I proceeded to do an acoustic study of $\mathrm{S}$. $\mathrm{Pa}-\mathrm{O}$ tones to complete the whole picture on $\mathrm{Pa}-\mathrm{O}$ tones with empirical evidence from the two dialects.

During my data collection, I observed that $\mathrm{S}$. Pa-O male and female speakers produced some tones differently. The S. $\mathrm{Pa}-\mathrm{O}$ informants also reported that they were able to sense the different characteristics of the males' and the females' tones. However, they could not specify exactly how the males' and the females' tones were different. 
The objectives of this study are to do an acoustic study of $\mathrm{S}$. Pa-O lexical tones and to investigate whether gender has an effect on the acoustic characteristics of $\mathrm{S}$. Pa-O tones or not. The study aims to make a contribution to the acoustic sociotonetic study of lexical tones of $\mathrm{S}$. $\mathrm{Pa}-\mathrm{O}$, an under-studied language of the SinoTibetan family.

\section{Phonological sketch of S. Pa-O}

The consonant, vowel and tone phonemes of $\mathrm{S}$. Pa-O are given in Tables 1, 2 and 3. $\mathrm{S}$. Pa-O has 20 consonants, 11 vowels and 6 tones. Seven consonants $(/ \mathrm{p} /, / \mathrm{t} /, / \mathrm{k} /, / \mathrm{R} /$, $/ \mathrm{m} /, / \mathrm{n} /, / \mathrm{n} /$ ) occur in both syllable-initial and syllable-final positions. The others are initial consonants only. Nine vowels are monophthongs occurring in both open and closed syllables; two are diphthongs occurring only in open syllables. Vowel length is not contrastive. There are 4 tones in non-checked syllables and 2 tones in checked syllables (with final /p/, /t/, / / / or /?/).

\section{Methodology}

\subsection{Speakers}

The speakers measured were native speakers of $\mathrm{S}$. Pa-O, comprising 5 males referred to as M1-5, and 5 females referred to as F1-5. Their ages ranged from $20-30$ years old. They were originally from Thaton, Mon State, Myanmar. They migrated into Thailand and lived along the Thai-Myanmar border for a few years. Then they moved to Bangkok. All 10 speakers have now been living and working in a $\mathrm{S}$. Pa-O community around Rama II Road for 6-8 years. Their first language is $\mathrm{S}$. $\mathrm{Pa}-\mathrm{O}$, and their second language is Thai. S. Pa-O males work as factory workers and $\mathrm{S}$. Pa-O females work as housemaids. They have no known history of speech or hearing impairment.

\subsection{Corpus}

The recorded syllables were 18 monosyllabic words with 4 syllable types: open syllables $(\mathrm{CV})$, nasal-final syllables $(\mathrm{CVN})$, glottal-final syllables (CVP), and stop-final syllables (CVS). All initial consonants were voiceless stops with either aspiration or unaspiration. The aspiration had an effect on F0 onset perturbation, not the entire F0 excursion. The vowels were controlled to be high or mid-high vowels ${ }^{3}$ in order to minimize the influence of intrinsic F0.

\footnotetext{
${ }^{3}$ To study tones acoustically, the low central unrounded /a/ is most frequently chosen for test words because it would certainly minimize an intrinsic F0 perturbation. However, high or mid-high vowels were controlled in this paper, which is part of my Ph.D. dissertation on citation tones and tonal coarticulation in $\mathrm{Pa}-\mathrm{O}$ continuous speech. If the vowel $/ a /$ is controlled, there will not be enough test words in the tonal coarticulation wordlist.
} 
MANUSYA: Journal of Humanities Regular 18.2, 2015

Table $1 \mathrm{~S}$. Pa-O consonant inventory

\begin{tabular}{|c|c|c|c|c|c|}
\hline & Labial & Alveolar & Palatal & Velar & Glottal \\
\hline Plosive & $\mathrm{p} \mathrm{p}^{\mathrm{h}} \mathrm{b}$ & $\mathrm{t} \quad \mathrm{t}^{\mathrm{h}} \mathrm{d}$ & $c c^{h}$ & $\mathrm{k} \mathrm{k}^{\mathrm{h}}$ & ? \\
\hline $\begin{array}{l}\text { Nasal } \\
\text { Fricative }\end{array}$ & $\mathrm{m}$ & s & & $\mathrm{y}$ & $\mathrm{h}$ \\
\hline Trill & & $\mathrm{r}$ & & & \\
\hline Approximant & w & 1 & $\mathrm{j}$ & & \\
\hline
\end{tabular}

Table 2 S. Pa-O vowel inventory

\begin{tabular}{|c|c|c|c|c|}
\hline & & Front & Central & Back \\
\hline \multirow{4}{*}{ Monophthongs } & High & $\mathrm{i}$ & $\dot{\mathrm{i}}$ & $\mathrm{u}$ \\
\hline & High-mid & $\mathrm{e}$ & & o \\
\hline & Low-mid & $\varepsilon$ & & o \\
\hline & Low & \multicolumn{3}{|c|}{$\mathrm{a}$} \\
\hline Diphthongs & & & $\mathrm{au}$ & \\
\hline
\end{tabular}

Table $3 \mathrm{~S}$. Pa-O tone inventory

\begin{tabular}{|c|c|c|c|}
\hline Non-checked syllables & & Checked syllables & \\
\hline Tone 1 & $/ 55 /$ & Tone 5 & /45/ \\
\hline Tone 2 & /33/ & & \\
\hline Tone 3 & $/ 31 /$ & Tone 6 & $/ 21 /$ \\
\hline Tone 4 & /53/ & & \\
\hline
\end{tabular}


Wordlist

Tone $1 / \mathrm{p}^{\mathrm{h}} \mathrm{u}^{55} /$ 'younger person' $/ \mathrm{k}^{\mathrm{h}} \mathrm{om}^{55} /$ 'to insult' $/ \mathrm{ton}^{55} /$ 'to toll'

Tone $2 / \mathrm{p}^{\mathrm{h}} \mathrm{u}^{33} /$ 'beehive' / $/ \mathrm{kom}^{33} /$ 'bottom' $/ \mathrm{con}^{33} /$ 'couple'

Tone $3 / \mathrm{p}^{\mathrm{h}} \mathrm{u}^{31} /$ 'father-in-law' / $/ \mathrm{Pom}^{31} /$ 'to keep in the mouth' $/ \mathrm{con}^{31} /$ 'cold'

Tone $4 / \mathrm{p}^{\mathrm{h}} \mathrm{u}^{53} /$ 'road' $/ \mathrm{kom}^{53} /$ 'two hundred' / $/ \mathrm{con}^{53} /$ 'thicket'

Tone $5 /$ ti $P^{45} /$ 'to bump against' /top ${ }^{45}$ '(paper) folded' / $/ \operatorname{cok}^{45} /$ 'sharp metal stick'

Tone $6 / \mathrm{tit}^{21} /$ 'west' /top ${ }^{21}$ 'to hit (with a fist)' / $\operatorname{cok}^{21} /$ 'to suck'

All of the test words in the wordlist are original S. Pa-O words. The words $/ \mathrm{Pom}^{31}$ / 'to keep in the mouth', /top ${ }^{45}$ / '(paper) folded', and /top ${ }^{21} /$ 'to hit (with a fist)' are accidentally similar to the Thai words $/ \mathrm{Pom}^{33} /$ 'to keep in the mouth', $/ \mathrm{t}^{\mathrm{h}} \mathrm{op}^{45} /$ to fold, fold (CLF), and $/$ top $^{21}$ / 'to slap'. They are not Thai loanwords with tone adaptation and semantic shift. These three S. Pa-O words are the same as those of N. Pa-O in Myanmar.

\subsection{Recordings and measurements}

Recordings were made in a quiet office of the $\mathrm{Pa}-\mathrm{O}$ Education Project, located on Rama II Road, Bangkok, Thailand. A highquality desktop microphone was positioned approximately $30 \mathrm{~cm}$. from the speakers. Three repetitions of the entire wordlist were recorded. The test words in the wordlist were randomized. To elicit the data, the author said Thai glosses to the speakers; then they said those words in $\mathrm{S}$. Pa-O. The total number of tokens was 540: 6 (tones) $\mathrm{x}$ 3 (sets) x 3 (times) x 10 (speakers). F0 was measured at every 0.01 second of syllable rhyme durations using PRAAT program version 5.3.60. Mono recordings and default sampling frequency of 44,100 Hertz were selected for recording.

\subsection{F0 normalization and generating $2^{\text {nd }}$ degree polynomial trendlines}

This study aims to investigate the F0 differences which are not related to the different physiology of male and female speakers because the different fundamental frequencies (F0) of males and females are well-documented. Males have lower fundamental frequencies than females; in other words, males have lower pitch than females (Coleman, 1976; Laver, 1994; Murry and Singh, 1980). This F0 difference results from the different physiology of the larynx. Therefore, F0 in Hertz varying based on the different size of the larynx was converted into semitones to normalize crossspeaker differences. The F0 ranges at different F0 heights were normalized to fit in semitone scales. The formula is semitones $=$ $12 \times \log _{2}$ (Hertz to be translated / Hertz reference). The reference value was the lowest Hertz for each speaker across all tones.

Generally, in order to present the acoustic characteristics of lexical tones, a line graph is used to show F0 which is measured at 5 points or 11 points of duration. In other words, F0 is measured at every $25 \%$ or $10 \%$ of the normalized duration. This method ignores duration which is another important dimension of tones. When the duration is normalized, the pitch shape is distorted. To 
illustrate, pitch falls gradually with long duration but falls steeply with short duration. In Jitwiriyanont (2012)'s study of Ban Pa La-U Sgaw Karen tones, the graphs displaying pitch characteristics of tones with normalized time were compared with those with real time. It revealed that normalized duration resulted in distorted pitch shape.

Figure 1 shows $\mathrm{F} 0$ converted into semitones, at every $10 \%$ of normalized duration of $\mathrm{S}$. $\mathrm{Pa}-\mathrm{O}$ tones (Speaker 1). It demonstrates that Tone 2 (T2) and Tone 6 (T6) are similar. This points out that in the case of S. Pa-O, some tones cannot be differentiated with normalized duration.

To solve the problem caused by the fact that normalizing duration distorts F0 shapes and to investigate exact F0 characteristics, I use the method of applying a $2^{\text {nd }}$ degree polynomial equation to present F0 characteristics of $\mathrm{S}$. Pa-O tones. The strength of this method is that real time values are used to generate trendlines showing F0 characteristics of lexical tones. As shown in Figure 2, with real duration, T2 and T6 are different. T2 is twice as long as T6, which can differentiate $\mathrm{T} 2$ from T6. This emphasizes that duration is another important dimension of tones.

Semitone and real time values were used to generate $2^{\text {nd }}$ degree polynomial or quadratic trendlines to show F0 contours and shapes. The original method was proposed by Andruski and Costello (2004). In Andruski and Costello's method, the lowest Hertz of each tone was subtracted to equal zero semitone. As a result, the y-axis (vertical dimension) did not show the F0 height but the amount of F0 change. In this present study, I adapted Anduski and Costello's method by using the lowest Hertz across all tones as the only reference Hertz to be substituted into the formula for converting Hertz into semitones. Consequently, for each speaker, only one point of all tones was subtracted to equal zero semitone, and the yaxis represented F0 height. The adapted method brought about trendlines representing F0 height, contour and shape, as illustrated in Figures 4 and 5.

\subsection{F0 contours and F0 shapes}

In this study, F0 characteristics are described by means of F0 contours and shapes. The combination of F0 contours and shapes results in F0 patterns. There are 5 types of contours: level, falling, rising, falling-rising, and rising-falling. The criterion for analyzing F0 contour is the relative values of three points: F0 onset, midpoint and offset as follows:

Level - the onset, the midpoint and the offset should be almost equal. The total of F0 excursion lies within 1 semitone. Rietveld and Gussenhoven (1985) carried out an experiment which found that a difference of semitones causing the perception of prominence was at least 1.5 semitones.

Falling - the onset is higher than midpoint and the midpoint is higher than the offset. The F0 movement is in the same direction.

Rising - the onset is lower than midpoint and the midpoint is lower than the offset. The F0 movement is in the same direction.

Falling-rising - the onset and the offset are higher than the midpoint. The F0 movement 


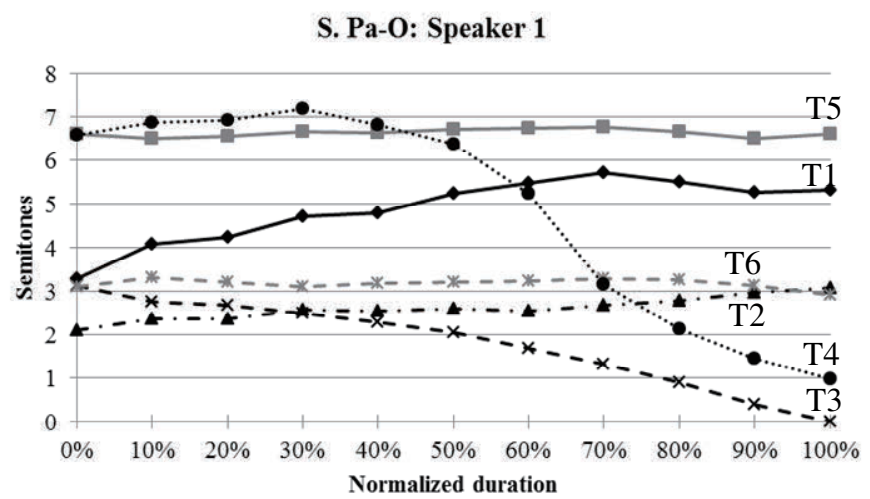

Tone $1 \quad-\cdots-\cdots$ Tone $2 \quad----$ Tone 3

……..... Tone $4 \longrightarrow$ Tone $5 \quad----$ Tone 6

Figure 1 Semitone values of S. Pa-O lexical tones (normalized duration)

\section{S. Pa-O: Speaker 1}

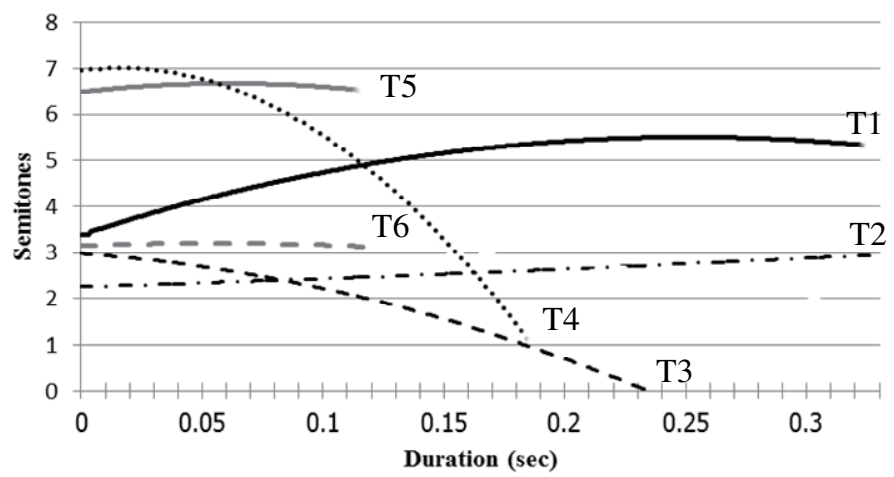

— Tone $1 \quad-\cdot-\cdot$ Tone $2 \quad---$ - Tone $3 \quad \cdots \cdots \cdots \cdot \cdots$ Tone $4 \quad$ Tone $5 \quad----$ Tone 6

Figure 2 Quadratic trendlines of S. Pa-O lexical tones (real duration), using my adapted method 
F0 contours

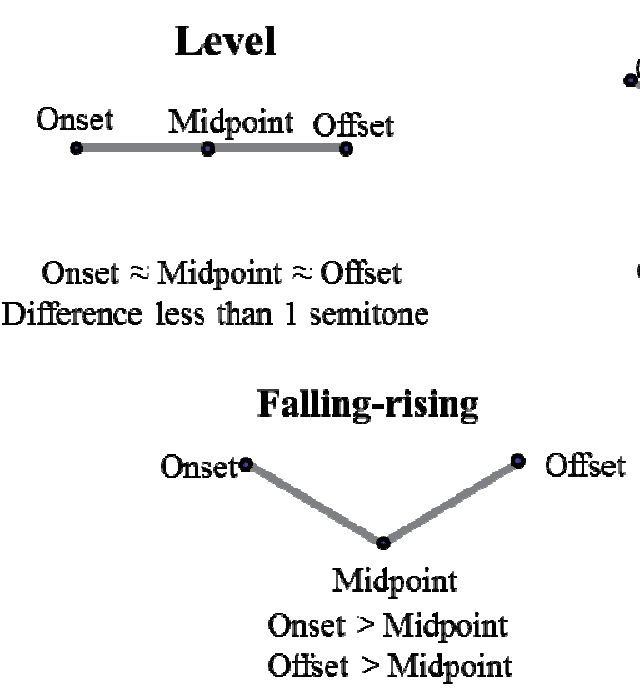

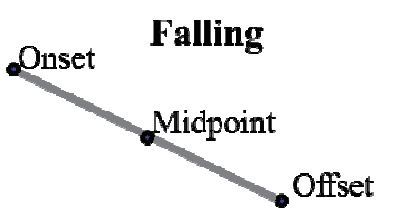

Onset $>$ Midpoint $>$ Offset

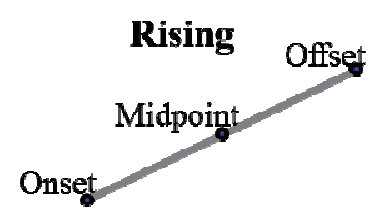

Onset $<$ Midpoint $<$ Offset

F0 shapes
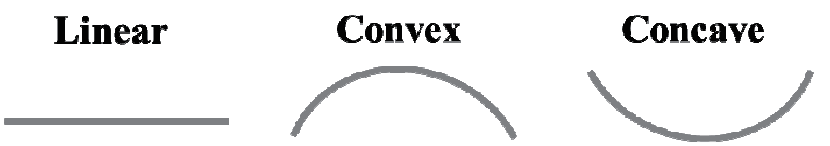

Figure 3: F0 contours and F0 shapes 
comprises two directions: falling from the onset to the midpoint and rising from the midpoint to the offset.

Rising-falling - the onset and the offset are lower than the midpoint. The F0 movement comprises two directions: rising from the onset to the midpoint and falling from the midpoint to the offset.

Apart from F0 contours, another aspect of F0 characteristics is F0 shapes. There are three types of shapes which are linear, convex and concave. Figure 3 is the summary and illustration of F0 contours and shapes.

\section{Results}

Each trace in the line graphs is the quadratic trendline generated from the mean F0 values across three syllables of the same tone repeated three times. Despite detailed difference of $\mathrm{F} 0$ height, contour and shape, the six tones of each speaker reflect some similar patterns across speakers, as shown in Figures 4 and 5 . The following presents the F0 characteristics of variants of each tone. The effects of gender on F0 characteristics of tones are evident.

\section{Tone 1 (T1)}

The F0 distribution of $\mathrm{T} 1$ is in the mid-high range. There are three variants of $\mathrm{T} 1$ : rising, falling-rising, and level.

\section{Rising variants (M1, F2, F3, F4, F5)}

The majority of the rising variants were produced by the females. The rising variants start in the mid or mid-high range and rise to a higher offset in the mid-high or high range. The F0 shapes of the rising variants are concave, convex, and linear.

2. Falling-rising variants (M2, M3, M4) All of the falling-rising variants were produced by the males. The falling-rising variants start in the mid or mid-high range, fall to the lower midpoints, and rise to higher offsets. The F0 shape of the fallingrising variants is concave.

\section{Level variants (M5, F1)}

The level variants are produced by both male and female speakers. Although they are categorized into level variants because the F0 difference between the onsets and the offsets is less than 1 semitone, the characteristics of F0 are not exactly level but variants is widely convex. 


\section{Male speakers}
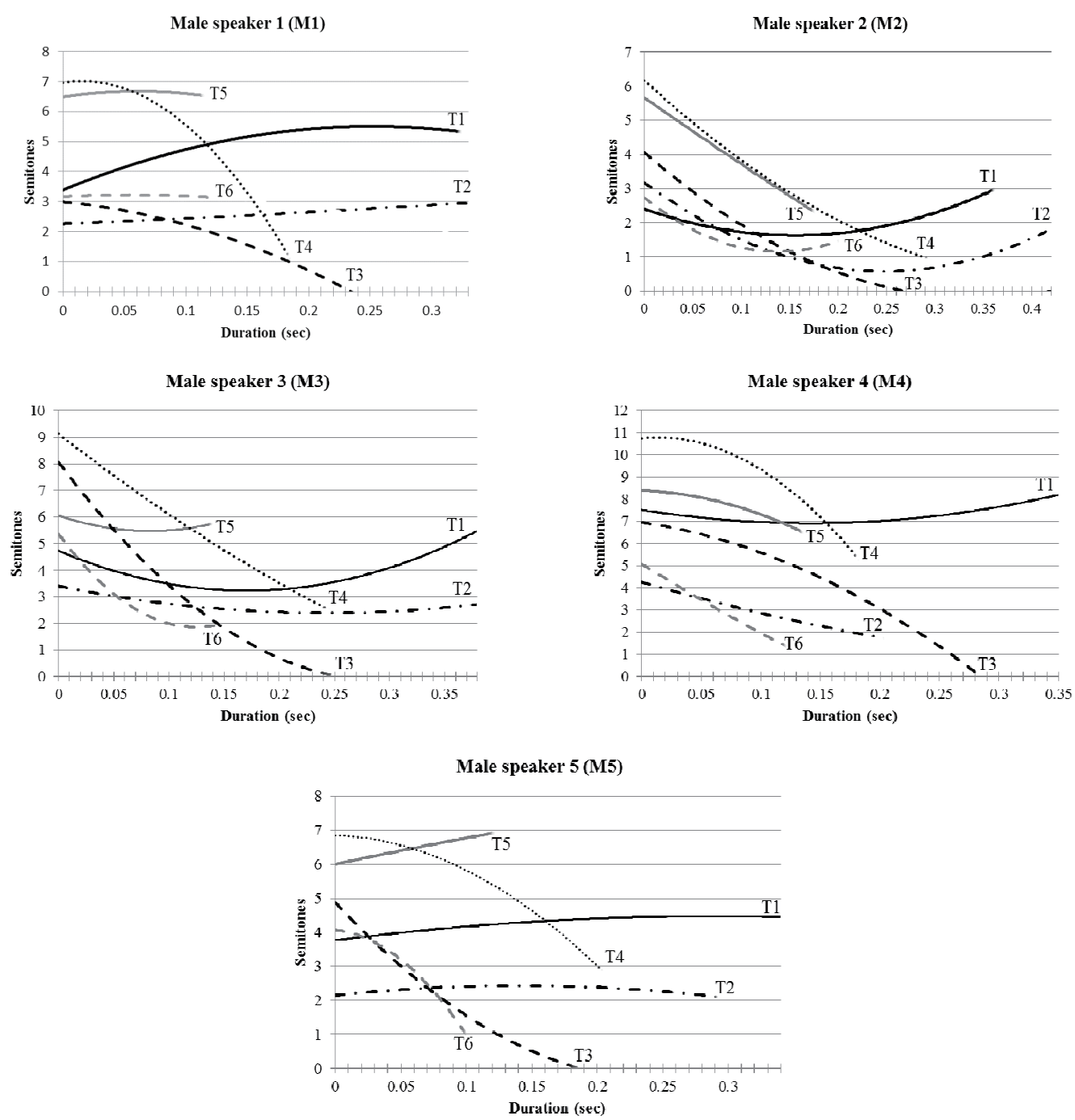

— Tone 1 -.-.-Tone 2 ---- Tone 3 -....... Tone 4 - Tone 5 ---- Tone 6

Figure 4 Quadratic trendlines of S. Pa-O lexical tones produced by 5 male speakers 


\section{Female speakers}
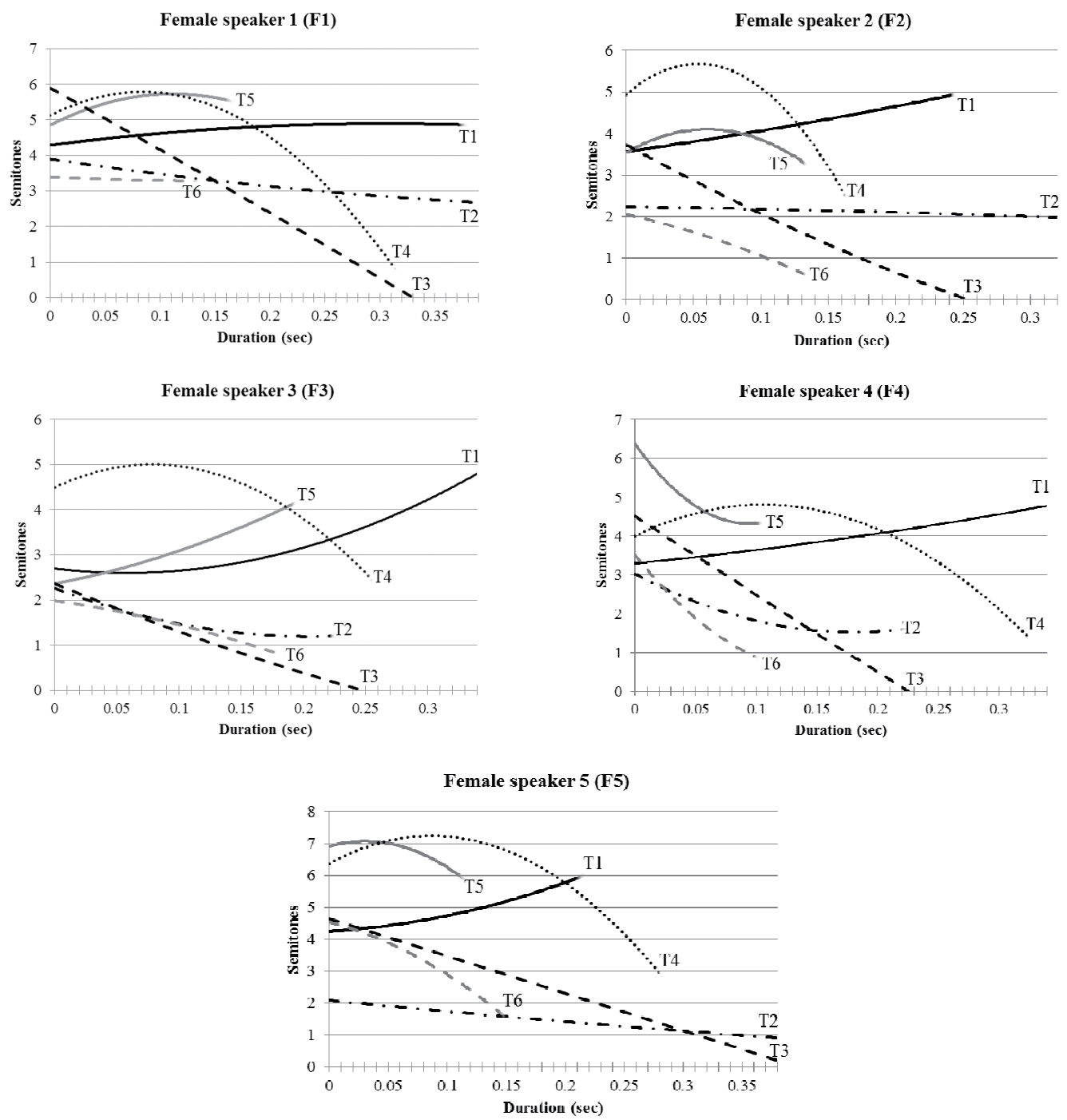

— Tone 1 -..-.-Tone 2 ---- Tone 3 -....... Tone 4 - Tone 5 ---- Tone 6

Figure 5 Quadratic trendlines of S. Pa-O lexical tones produced by 5 female speakers 

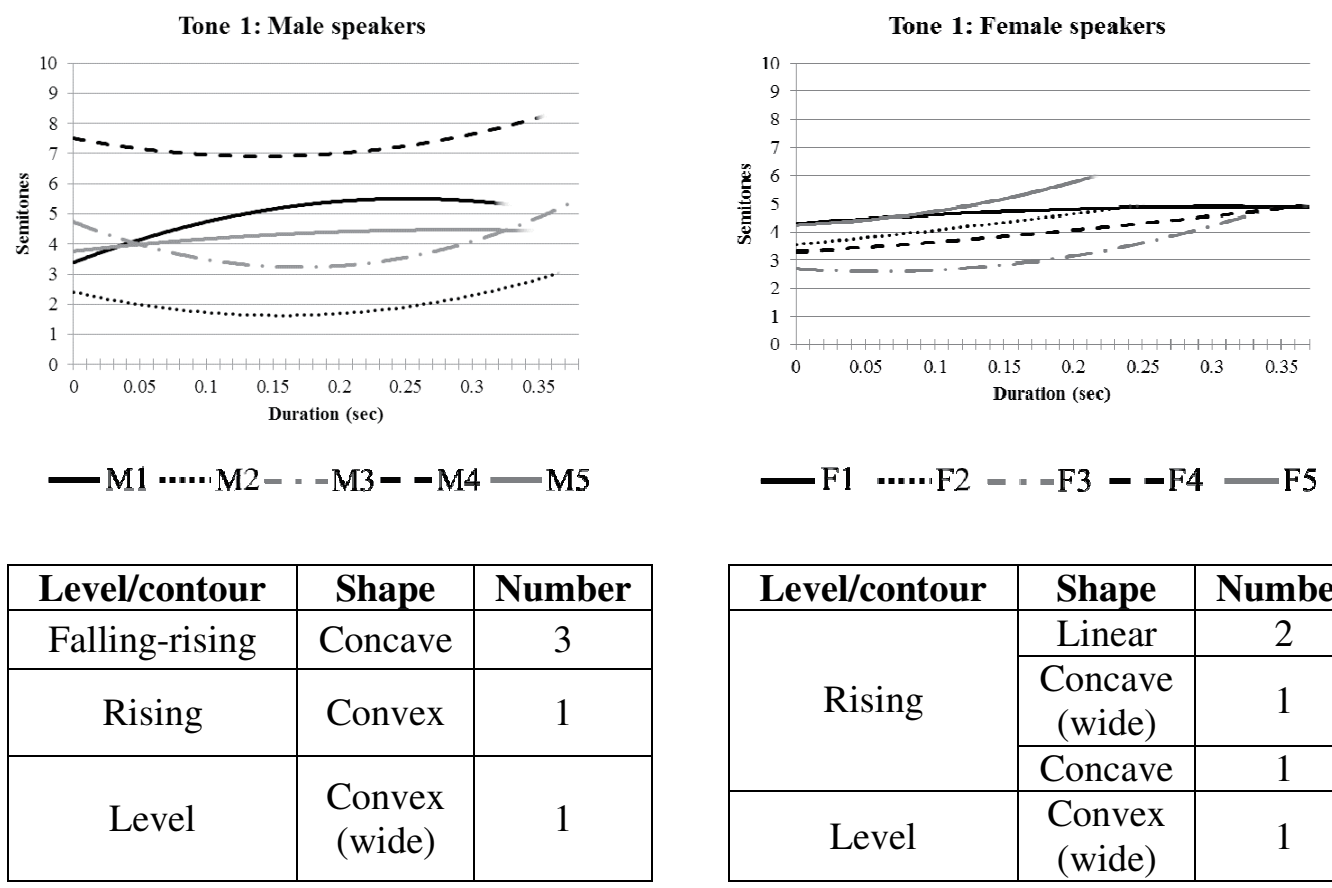

\begin{tabular}{|c|c|c|}
\hline Level/contour & Shape & Number \\
\hline \multirow{4}{*}{ Rising } & Linear & 2 \\
\cline { 2 - 3 } & $\begin{array}{c}\text { Concave } \\
\text { (wide) }\end{array}$ & 1 \\
\cline { 2 - 3 } Concave & 1 \\
\hline \multirow{2}{*}{ Level } & $\begin{array}{c}\text { Convex } \\
\text { (wide) }\end{array}$ & 1 \\
\hline
\end{tabular}

Figure 6 Quadratic trendlines of Tone 1 produced by male and female speakers

The property which the three variants have in common is a rising cue. It is noticeable that the rising parts of both rising variants and falling-rising variants are from midpoints to offsets. The level variants are also rising with a small amount of F0 difference.

It is observable that Figure 6 not only illustrates the F0 contours and shapes but also suggests that the F0 ranges of the males are larger than those of the females. The trendlines of the males' $\mathrm{T} 1$ disperse over a wider area as seen in Figures 4 and 5. F0 range is the difference between the lowest and the highest pitch values (semitones in this study). As the lowest Hertz of each speaker was converted to 0 semitone, the highest semitone equals F0 range. The males' F0 ranges are 7-11 semitones; the females' are 6-7 semitones. The T1 trace on the top at around 7 semitones, in Figure 6, belongs to M4. It is relatively higher than the others as the F0 range of M4 is the largest at, 11 semitones. However, it is relatively the same proportion when compared to the overall ranges of the other speakers as Figures 4 and 5 show. Therefore, the F0 height of the variants should not be compared across speakers owing to the relative nature of tone. Tones are scaled relative to an individual's pitch range (Dilly, 2005). 
Tone 2 (T2)

The F0 distribution of $\mathrm{T} 2$ is in the mid range. There are three variants of $\mathrm{T} 2$ : falling, falling-rising and level.

\section{Falling variants (M4, F1, F3, F4, F5)}

The majority of the falling variants were produced by the females. Typically, the falling variants start in the mid range and fall to the mid-low range (M4, F3, F4). There is some variation regarding F0 height as in F1 and F5. T2 of F1 starts mid-high and falls to mid range. The onset, the midpoint, and the offset of F5 are all in the mid-low range. However, the tones of F1 and F5 still reflect the same falling contour as the majority. The F0 shapes of the falling variants are linear and concave.

\section{Falling-rising variant (M2)}

The falling-rising variant was produced by only M2. The variant starts in the mid range, falls to a lower midpoint, and rises to a higher offset. It somewhat resembles the falling variant, but it has an ascending part in the last $25 \%$ of the F0 excursion. It is noted that it is M2's individual idiosyncrasy that most of his tones have ascending parts in the end as shown in Figure 4.

\section{Level variants (M1, M3, M5, F2)}

Almost all of the level variants are produced by the males. The F0 values remain level in either the mid range (M1, F2) or the midlow range (M3, M5). The F0 shapes of the level variants are linear and widely concave or convex.

\section{Tone 3 (T3)}

Despite the different $\mathrm{F} 0$ ranges of $\mathrm{T} 3$ across speakers, the tonal identity of $\mathrm{T} 3$ is the lowest offset. The tones start in the mid-high, high or mid range but uniformly fall to the lowest point in the semitone scale. Both the male and the female speakers have the offset at 0 semitone.

Unlike the case of $\mathrm{T} 1$ and $\mathrm{T} 2$ where $\mathrm{F} 0$ contours can distinguish the tones of the different-gender speakers, the difference between the males and the females' T3 lies in F0 shape. While the F0 shapes of the males' T3 are either concave or convex, the F0 shapes of the females' T3 are all linear, as shown in Figure 8.

\section{Tone 4 (T4)}

T4 is either high falling or high rising-falling pitch. All of the males have falling variants while all of the females have rising-falling variants. There is a rigid dichotomy between the males' and the females' F0 contours of T4, as shown in Figure 9.

1. Falling variants (M1, M2, M3, M4, M5) The falling variants of the males start in the high range and fall to the mid-low or low range. The $\mathrm{F} 0$ shapes of the falling variants are convex, widely concave, or linear.

2. Rising-falling variants (F1, F2, F3, F4, F5) The rising-falling variants of the females start in the high or mid-high range, rise to a higher midpoint and fall to the mid or midlow range. The F0 shape of the rising-falling variants is convex. 

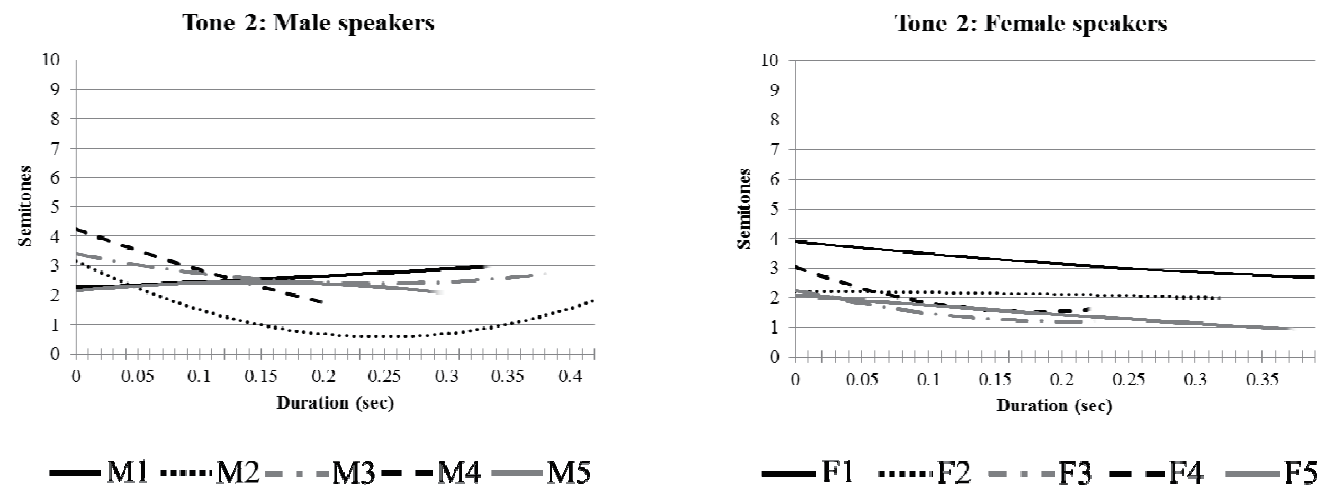

\begin{tabular}{|c|c|c|}
\hline Level/contour & Shape & Number \\
\hline \multirow{4}{*}{ Level } & Linear & 1 \\
\cline { 2 - 3 } & $\begin{array}{c}\text { Concave } \\
\text { (wide) }\end{array}$ & 1 \\
\cline { 2 - 3 } & $\begin{array}{c}\text { Convex } \\
\text { (wide) }\end{array}$ & 1 \\
\hline Falling & Linear & 1 \\
\hline Falling-rising & Concave & 1 \\
\hline
\end{tabular}

\begin{tabular}{|c|c|c|}
\hline Level/contour & Shape & Number \\
\hline \multirow{3}{*}{ Falling } & Linear & 2 \\
\cline { 2 - 3 } & $\begin{array}{c}\text { Concave } \\
\text { (very wide) }\end{array}$ & 1 \\
\cline { 2 - 3 } & Concave & 1 \\
\hline Level & Linear & 1 \\
\hline
\end{tabular}

Figure 7 Quadratic trendlines of Tone 2 produced by male and female speakers
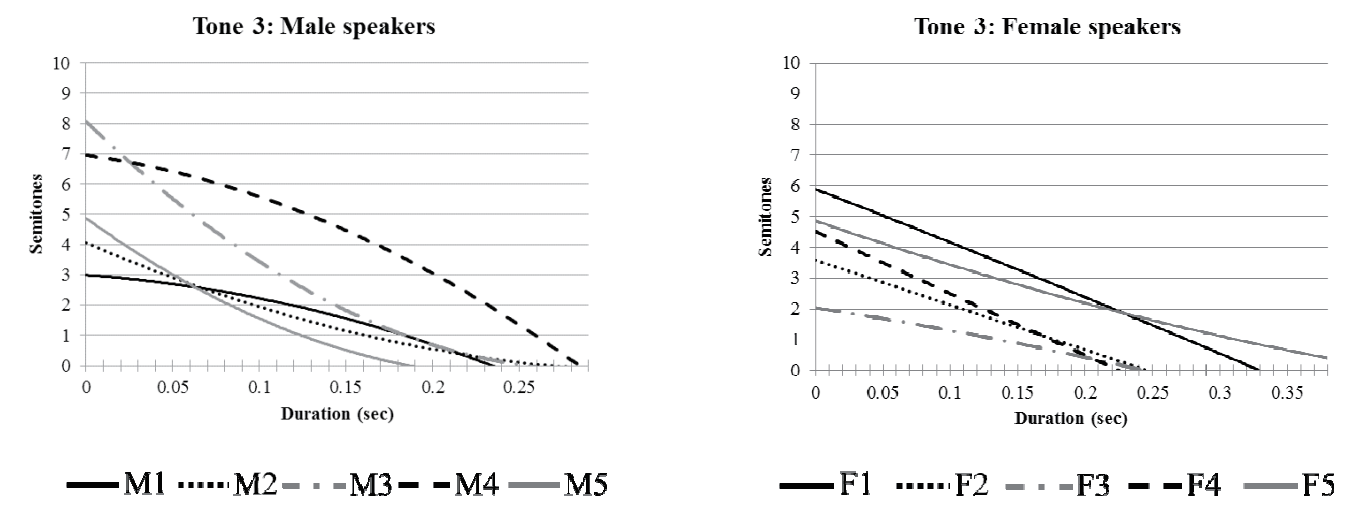

\begin{tabular}{|c|c|c|}
\hline Level/contour & Shape & Number \\
\hline \multirow{2}{*}{ Falling } & Concave & 3 \\
\cline { 2 - 3 } & Convex & 2 \\
\hline
\end{tabular}

\begin{tabular}{|c|c|c|}
\hline Level/contour & Shape & Number \\
\hline Falling & Linear & 5 \\
\hline
\end{tabular}

Figure 8 Quadratic trendlines of Tone 3 produced by male and female speakers 

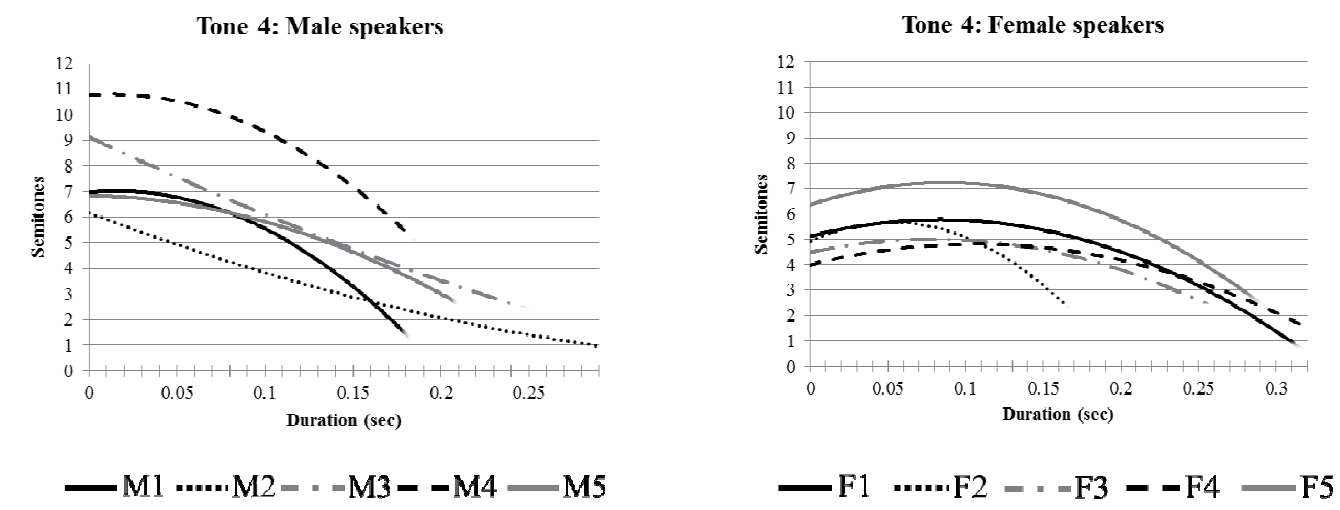

\begin{tabular}{|c|c|c|}
\hline Level/contour & Shape & Number \\
\hline \multirow{4}{*}{ Falling } & Convex & 3 \\
\cline { 2 - 3 } & Linear & 1 \\
\cline { 2 - 3 } & $\begin{array}{c}\text { Concave } \\
\text { (very } \\
\text { wide) }\end{array}$ & 1 \\
\hline
\end{tabular}

\begin{tabular}{|c|c|c|}
\hline Level/contour & Shape & Number \\
\hline Rising-falling & Convex & 5 \\
& & \\
\hline
\end{tabular}

Figure 9 Quadratic trendlines of Tone 4 produced by male and female speakers

Despite the difference of the early parts, the two variants have a similar falling F0 movement with a large degree of F0 change. Descending from the high and mid-high range, the two variants end in the mid or mid-low range. The falling cue is auditorily and acoustically obvious.

\section{Tone 5 (T5)}

The F0 distribution of $\mathrm{T} 5$ is in the high range. The duration is short. There are four variants: falling, rising, level, and risingfalling combined with all F0 shapes. There are various $\mathrm{F} 0$ characteristics: convex falling (M4, F5), linear falling (M2), concave falling (F4), convex rising (F1), concave rising (F3), linear rising (M5), convex level
(M1), concave level (M3), and convex rising-falling (F2), as shown in Figure 10.

Despite the various F0 contours and shapes, the whole F0 change is relatively the highest in the F0 range. On account of fuzzy F0 characteristics, there is no distinguishable F0 pattern between the males' and the females' T5.

\section{Tone 6 (T6)}

The F0 distribution of $\mathrm{T} 6$ is in the mid range. The duration is short. There are two variants of T6: falling and level. 

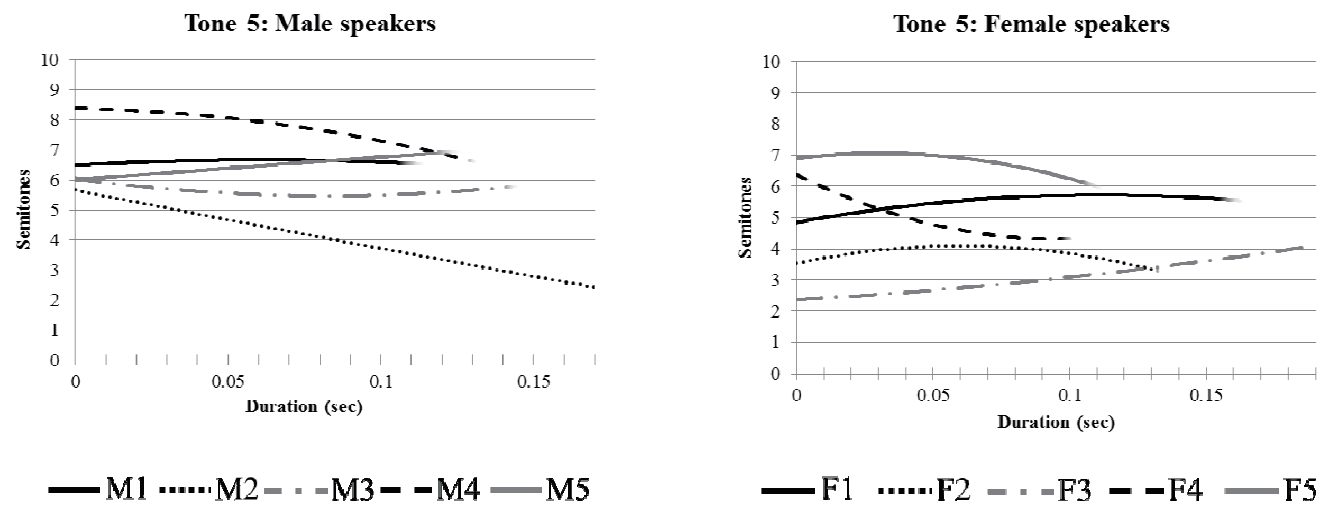

\begin{tabular}{|c|c|c|}
\hline Level/contour & Shape & Number \\
\hline \multirow{7}{*}{ Level } & $\begin{array}{c}\text { Convex } \\
\text { (very } \\
\text { wide) }\end{array}$ & 1 \\
\cline { 2 - 3 } & $\begin{array}{c}\text { Concave } \\
\text { (very } \\
\text { wide) }\end{array}$ & 1 \\
\hline \multirow{4}{*}{ Falling } & Linear & 1 \\
\cline { 2 - 3 } & $\begin{array}{c}\text { Convex } \\
\text { (very } \\
\text { wide) }\end{array}$ & 1 \\
\hline Rising & Linear & 1 \\
\hline
\end{tabular}

\begin{tabular}{|c|c|c|}
\hline Level/contour & Shape & Number \\
\hline \multirow{2}{*}{ Rising } & Convex & 1 \\
\cline { 2 - 3 } & $\begin{array}{c}\text { Concave } \\
\text { (very } \\
\text { wide) }\end{array}$ & 1 \\
\hline \multirow{2}{*}{ Falling } & Convex & 1 \\
\cline { 2 - 3 } Rising-falling & Concave & 1 \\
\hline Convex & 1 \\
\hline
\end{tabular}

Figure 10 Quadratic trendlines of Tone 5 produced by male and female speakers. 

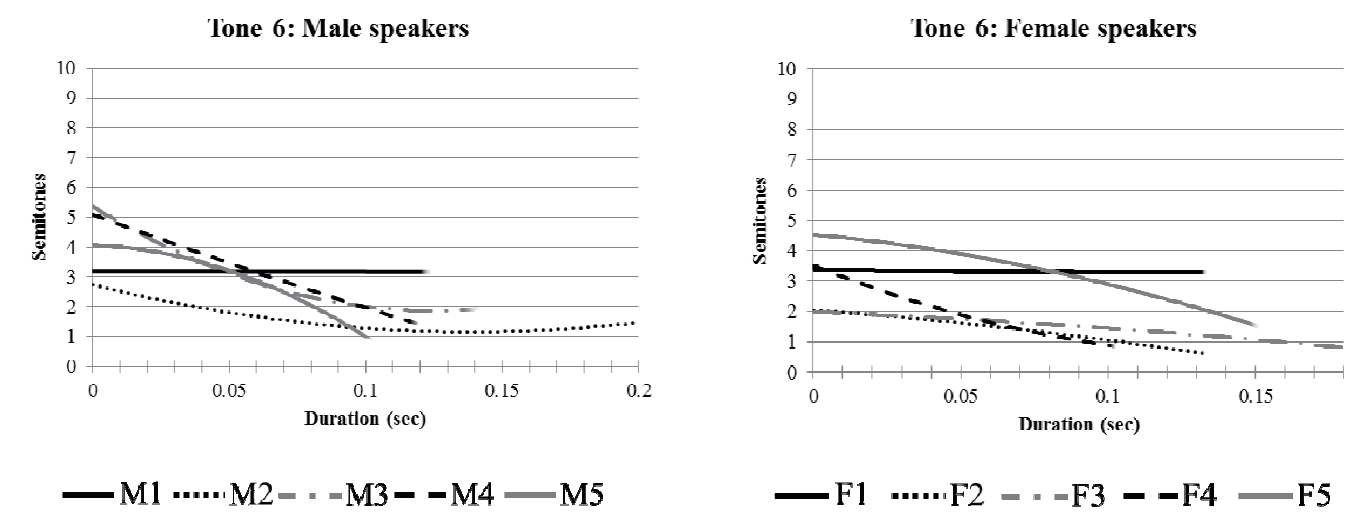

\begin{tabular}{|c|c|c|}
\hline Level/contour & Shape & Number \\
\hline \multirow{3}{*}{ Falling } & Concave & 2 \\
\cline { 2 - 3 } & Convex & 1 \\
\cline { 2 - 3 } & Linear & 1 \\
\hline Level & Linear & 1 \\
\hline
\end{tabular}

\begin{tabular}{|c|c|c|}
\hline Level/contour & Shape & Number \\
\hline \multirow{3}{*}{ Falling } & Convex & 2 \\
\cline { 2 - 3 } & Concave & 1 \\
\cline { 2 - 3 } & Linear & 1 \\
\hline Level & Linear & 1 \\
\hline
\end{tabular}

Figure 11 Quadratic trendlines of Tone 6 produced by male and female speakers

1. The falling variants (M2, M3, M4, M5, F2, F3, F4, F5)

Most of both the male and the female speakers' T6 variants are falling contour. They start in the mid range and fall to lower offsets in the mid-low range. F5 has the onset in the mid-high range; however, the offset also reaches the mid-low range. The F0 shapes of the falling variants are concave, convex, and linear.

2. The level variants $(\mathrm{M} 1, \mathrm{~F} 1)$

Only one male and one female have level variants of T6. They maintain the F0 level in the mid range. The F0 shape of level variants is linear.

The males and the females have the same F0 contours of T6 with similar F0 shapes between the two genders. There is no distinguishable F0 pattern between the males' and the females' T6.

It is observable that some speakers, i.e. M4 and F5, produced some particular tones with duration shortening. M4's T2 and F5's T1 look quite short. The duration shortening of $\mathrm{T} 2$ occurs in M4. The F0 contour is falling. The offset of $\mathrm{T} 2$ is lower than the onset but never reaches the lowest point, which is the tonal characteristic of T3. The onset of M4 is in the mid range. It will not take a long duration to reach the offset target in the midlow range. As a result, the durations are shorter. When the F0 movement reaches the target in the mid-low range, it ends in order not to overlap with the F0 offset of T3 in the low range. 
A similar phenomenon is found in the $\mathrm{T} 1$ of F5 as well. F5 has an unexpectedly short duration of $\mathrm{T} 1$. The duration shortening could result from the fact that the F0 contour of F5's T1is rising with a great initial slope. As a result, they reach the offset target in the high range faster than normal. The compensation of shorter duration, therefore, occurs in order to prevent the F0 offset from reaching the extra-high range.

The duration variation does not affect the F0 shapes and contours. Besides, they can be considered as compensation for preserving the F0 characteristics of certain tones: $\mathrm{T} 2$ of M4 and T1 of F5.

\section{Conclusion and discussion}

This acoustic study reveals a gender effect in the acoustic characteristics of $\mathrm{S}$. Pa-O tones. With F0 normalization to minimize the physiological difference, the quadratic trendlines exhibit a gender-related pattern of F0 contours and shapes.

The differences of F0 characteristics between the male and the female speakers are found in the tones in non-checked syllables (T1, T2, T3, and T4). The two checked tones (T5 and T6) do not reflect distinguishable F0 characteristics. The F0 characteristics of T5 are very diverse, while those of T6 are rather uniform. Consequently, no different pattern between the males' and the females' tones can be generalized.

The F0 characteristics of $\mathrm{T} 1, \mathrm{~T} 2$ and $\mathrm{T} 4$ reflect the difference between genders in their F0 contours. The cases of T1 and T2 are a tendency; that of T4 is a dichotomy. In
$\mathrm{S}$. $\mathrm{Pa}-\mathrm{O}$, the males are more likely to produce $\mathrm{T} 1$ with falling-rising contour whereas the females are more likely to produce $\mathrm{T} 1$ with rising contour. The level variant is gender neutral. Likewise, the F0 contours of the males' $\mathrm{T} 2$ tend to be level while those of the females' $\mathrm{T} 2$ tend to be falling. Regarding $\mathrm{T} 4$, the difference is obvious. The males' T4 is falling, and the females' T4 is rising-falling as displayed at the opposite ends of the scale in Figure 17.

The F0 contours of male and female T3 are uniformly falling. Despite the various onsets, the tonal identity of T3 is its offset which is the lowest in each speaker's F0 range. However, T3 of the males and the females can be differentiated by the F0 shape. The difference is clear cut. The F0 shapes of the males' T3 are all curved, while those of the female T3 are linear. The gender-specific patterns of F0 characteristics are illustrated in Figures 14-17.

In S. Pa-O, male and female tones are acoustically different in terms of either F0 shapes or contours. The gender variation confirmed in this acoustic study supports males and females have different linguistic styles. The F0 difference was not caused by the different physiology of males and females as Hertz values were converted into semitones in this study. Consequently, the difference must be based on gender as a sociolinguistic factor, and not physiology.

In Bangkok, Thailand, S. Pa-O people live and work around Rama II Road where a number of factories are located. S. Pa-O people have high community closeness with language maintenance activities. They have 


Male \begin{tabular}{ccc} 
Folling-rising & $\begin{array}{c}\text { Tone } 1 \\
\text { Level }\end{array}$ & Rising \\
\cline { 2 - 3 } M2 M3 M4 & M5 & M1
\end{tabular}$\quad$ Female

Figure 14 Scales showing F0 contours of males and females' Tone 1

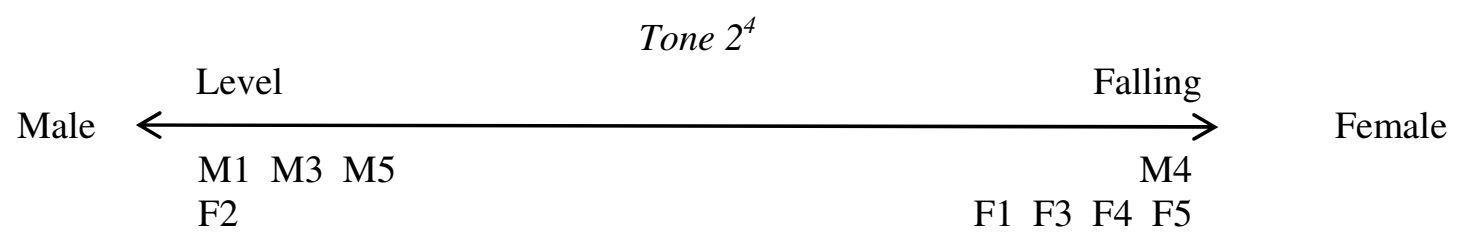

Figure 15 Scales showing F0 contours of males and females' Tone 2

Tone 3

\begin{tabular}{|c|c|c|}
\hline & Concave/convex falling & Linear falling \\
\hline
\end{tabular}

Figure 16 Scales showing F0 contours and shapes of males' and females' Tone 3

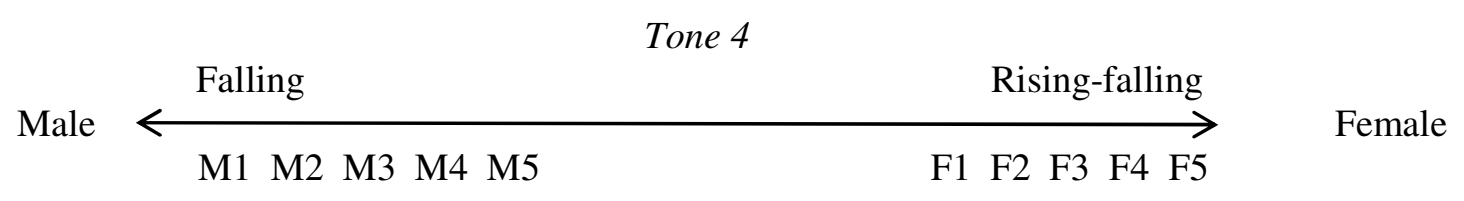

Figure 17 Scales showing F0 contours of males' and females' Tone 4

\footnotetext{
${ }^{4}$ The falling-rising variant of M2 is not included in Figure 15, for it is M2's individual idiosyncrasy of producing most tones with an ascending end.
} 
an office for the Pa-O Education Project (PEP) where they gather every Sunday.

$\mathrm{Pa}-\mathrm{O}$ people have limited career choices. $\mathrm{S}$. $\mathrm{Pa}-\mathrm{O}$ males work as factory workers and $\mathrm{S}$. $\mathrm{Pa}-\mathrm{O}$ females work as maids. Working in different kinds of workplaces, they have different opportunities to speak $\mathrm{S}$. Pa-O language during work time. Males working in factories full of $\mathrm{S}$. Pa-O male co-workers have more opportunities to speak S. Pa-O. In addition, their work does not require them to have a good command of Thai. They work with a machine and $\mathrm{S}$. $\mathrm{Pa}-\mathrm{O}$ peers. In contrast, the females working as maids have fewer opportunities to speak $\mathrm{S}$. Pa-O as they do not have to work in a team. Every day, the S. Pa-O males and females are kept separate with different activities most of the day. S. Pa-O males' work enhances gender solidarity as most of their peers are $\mathrm{S}$. Pa-O males whereas $\mathrm{S}$. Pa-O females' work does not as they work mostly alone.

Tannen (1990) argued that like people from different social and ethnic backgrounds, males and females live in different subcultures. In other words, men have different lifestyles, interests and worldviews, from women. Mostly, occupation is also related to gender. Tannen's argument is illustrated by the situation of the $\mathrm{S}$. $\mathrm{Pa}-\mathrm{O}$ in Thailand. S. Pa-O people have language maintenance activities on Sundays. Meanwhile, the males have gender maintenance on weekdays when they work.

\section{References}

Andruski, Jean E. and James Costello. 2004. Using Polynomial Equations to Model Pitch Contour Shape in Lexical Tones.
Journal of the International

Phonetic Association, 34, 125-140.

Burling, Robbins. 1969. Proto-Karen: A reanalysis. Occasional Papers of the Wolfenden Society on Tibeto-Burman Linguistics vol 1. Ann Arbor, MI: Department of Linguistics, University of Michigan.

Coleman, Ralph O. 1976. A Comparison of the Contributions of Two Voice Quality Characteristics to the Perception of Maleness and Femaleness in the Voice. Journal of Speech and Hearing Research, 19, 168-180.

Dilley, Laura C. 2005. The Phonetics and Phonology of Tonal Systems. Ph.D. Dissertation, MIT.

Jitwiriyanont, Sujinat. 2012. Ban Pa La-u Sgaw Karen Tones: an Analysis of Semitones, Quadratic Trendlines and Coefficients. Manusya, Vol. 15, No. 2.

Jones, Robert B. 1961. Karen Linguistic Studies: Description, Comparison and Texts. Berkeley: University of California Press.

Laver, John. 1994. Principles of Phonetics. Cambridge: Cambridge University Press.

Luangthongkum, Theraphan. 2014. ProtoKaren $\left({ }^{*} \mathrm{k}-\mathrm{rjay}{ }^{\mathrm{A}}\right)$ Fauna. Manusya, Special Issue 20, 86-123.

Murry, Thomas. and Sadanand Singh. 1980. Multidimensional Analysis of Male and Female Voices. Journal of the Acoustical Society of America, 68, 1294-1300. 
Rietveld, A.C.M. and Carlos Gussenhoven.

1985. On the Relation between Pitch

Excursion Size and Prominence.

Journal of Phonetics, 13, 299-308.

Tannen, Deborah. 1990. You Just don't

Understand: Women and Men in

Conversation. New York:

William Morrow.

Thanamteun, Orranat. 2000. The

phonological study of Pa-o (Taungthu) at

Ban Huay Salop,Tambon Huay Pha,

Muang District, Mae Hong Son. M.A.

Thesis, Mahidol University,

Nakhon Pathom. 